\title{
Are there any relationships between latent Toxoplasma gondii infection, testosterone elevation, and risk of autism spectrum disorder?
}

\author{
Amir Abdoli ${ }^{1,2 *}$ and Abdolhossein Dalimi ${ }^{2}$ \\ 1 Faculty of Medical Sciences, Department of Parasitology, Kashan University of Medical Science, Kashan, Iran \\ 2 Faculty of Medical Sciences, Department of Parasitology, Tarbiat Modares University, Tehran, Iran \\ *Correspondence: a.abdoli@modares.ac.ir, a.abdoli25@gmail.com \\ Edited by: \\ Jack Van Honk, Utrecht University, Netherlands \\ Reviewed by: \\ Bonnie Auyeung, University of Cambridge, UK \\ John Thomas Manning, Northumbria University, UK
}

Keywords: Toxoplasma gondii, prenatal testosterone, autism, extreme male brain theory, latent infection, second to fourth digit ratio, sex ratio

\section{AUTISM SPECTRUM DISORDER AND} THE "EXTREME MALE BRAIN" THEORY

Autism spectrum disorder (ASD) is a set of complex neurodevelopmental disorders. ASD is characterized by early-onset difficulties in social interaction, repetitive behavior, and verbal and non-verbal communication. Worldwide prevalence of ASD is about 1\% (Lai et al., 2014). Several factors have been proposed in the etiology of ASD, including genetics background, obstetric complications, intrauterine infections, environmental conditions, immune imbalance, and fetal testosterone levels (Rutter, 2005; Currenti, 2010; Ratajczak, 2011; Gesundheit et al., 2013; Goines and Ashwood, 2013; Jyonouchi, 2013; Lai et al., 2014). Autism affects males more frequently than females (Baron-Cohen et al., 2011; Werling and Geschwind, 2013; Developmental Disabilities Monitoring Network Surveillance Year 2010 Principal Investigators and Centers for Disease Control and Prevention, 2014), with ratios of 4:1 (male: female) for classic autism (Chakrabarti and Fombonne, 2001) and 11:1 in individuals with Asperger syndrome (AS) (Gillberg et al., 2006). This evidence raises an important question: what influencing factors are responsible for the higher male prevalence of autism? The exact answer to this question remains unclear; however, the "extreme male brain" theory of autism (Baron-Cohen, 2002) proposed that exposure to high levels of prenatal testosterone is one possible mechanisms (Baron-Cohen, 2002; Baron-Cohen et al., 2011).

\section{LATENT TOXOPLASMOSIS INFLUENCE TESTOSTERONE PRODUCTION}

Toxoplasmosis is one of the most common zoonotic diseases that has infected approximately one-third of the world's human population (Montoya and Liesenfeld, 2004). Although it is estimated between 25 and $30 \%$ of the world's human population is infected by $T$. gondii, and the most common form of infection is latent (asymptomatic) (Dalimi and Abdoli, 2012; Robert-Gangneux and Dardé, 2012). On the other hand, latent toxoplasmosis can induce different hormonal and behavioral alterations in humans and rodents (Flegr, 2013a,b) and involved in the etiology of various psychotic disorders (Dalimi and Abdoli, 2012; Flegr, 2013a; Abdoli et al., 2014). Different studies reported an increased concentration of testosterone in men with latent toxoplasmosis compared to the testosterone in Toxoplasmanegative individuals (Flegr et al., 2008a,b; Shirbazou et al., 2011; Zghair et al., 2014). Increased concentrations of testosterone were also confirmed in an animal model of latent toxoplasmosis (Lim et al., 2013). In addition, several indirect evidences exist for increased prenatal testosterone in latent toxoplasmosis (see the next sections). This condition raises an important question: does latent toxoplasmosis increase risk of ASD via mechanisms consistent with the "extreme male brain" theory of autism? If this hypothesis is correct, pregnant women with latent toxoplasmosis are more likely to give birth to a child with ASD. Hence, we summarize the evidences of increased prenatal testosterone in ASD and latent toxoplasmosis to offer a new insight into the role of T. gondii infection in the etiology of ASD.

\section{DIRECT EVIDENCES FOR INCREASED PRENATAL TESTOSTERONE IN AUTISTIC-LIKE TRAITS AND ASD}

There is both direct and indirect evidence for the role of prenatal testosterone and related androgens in the etiology of autistic traits and ASD. Recently, BaronCohen et al. (2014) found direct evidence of elevated fetal steroidogenic activity in ASD individuals from the Danish Historic Birth Cohort. In this study, concentrations of $\Delta 4$ sex steroids (testosterone, androstenedione, 17 $\alpha$-hydroxyprogesterone, and progesterone) and cortisol were measured in amniotic fluid samples of 128 males born between 1993 and 1999 who later received ICD-10 (International Classification of Diseases, 10th Revision) diagnoses of autism, AS or PDDNOS (pervasive developmental disorder not otherwise specified), compared with healthy controls. The results showed significant elevations of all hormones in ASD individuals (Cohen's $d=0.37, p=0.0009$ ).

Autistic-like traits are the first signs of ASD (Lundström et al., 2012). Moreover, individuals with one or more autistic traits also appear to be at higher risk for ASD, attention deficit hyperactivity disorder (ADHD), depression, and anxiety (Lundström et al., 2011). In this regard, a positive correlation between prenatal testosterone 
levels and higher scores on the childhood autism spectrum test (CAST) and Child Autism Spectrum Quotient (AQ-Child) were reported from the Cambridge Fetal Testosterone Project, which measured prenatal testosterone levels during amniocentesis and compared the numbers of autistic traits in toddlers (Auyeung et al., 2009, 2010). Moreover, boys scored higher on the Quantitative Checklist for Autism in Toddlers (Q-CHAT) than girls (Auyeung et al., 2009). Auyeung et al. (2012) compared the effects of prenatal versus postnatal testosterone and estradiol levels on the number of autistic traits among children between 18 and 24 months of age. The results of the Q-CHAT were positively associated with the levels of prenatal testosterone $(p<0.05)$ (but not postnatal testosterone or either prenatal or postnatal estradiol levels) (Auyeung et al., 2012). Another study by $\mathrm{Xu}$ and colleagues (Xu et al., 2013) revealed a significant higher level of plasma testosterone $(p<0.05)$ in mothers of autistic children compared to control subjects.

Congenital adrenal hyperplasia $(\mathrm{CAH})$ is a disease that leading to overproduction of adrenal androgens due to an enzyme deficiency [usually of 21 hydroxylase (21$\mathrm{OH})$ ] (Knickmeyer et al., 2006). Knickmeyer et al. (2006) reported that the total scores of AQ were significantly higher in females with $\mathrm{CAH}$ compared with unaffected females.

\section{INDIRECT EVIDENCES FOR INCREASED PRENATAL TESTOSTERONE IN ASD AND LATENT TOXOPLASMOSIS SECOND TO FOURTH DIGIT RATIO}

It is well documented that the ratio between the length of the second digit (the "index" finger) and the fourth digit (the "ring" finger) is an indicator of prenatal sex steroid levels (Manning, 2011; Zheng and Cohn, 2011; Manning et al., 2014). However, the role of adult sex steroids in this ratio is less clear (Hönekopp et al., 2007). The ratio of $2 \mathrm{D}: 4 \mathrm{D}$ is a sexually dimorphic trait that is different in male and female; it means that the ring finger relative to index finger is longer among males (low 2D:4D) than females (high 2D:4D) (Hönekopp and Watson, 2010).2D:4D ratio in males is negatively related to testosterone level; and in both sexes is positively related to estrogen level (Manning et al., 1998; Manning and
Bundred, 2000; Lutchmaya et al., 2004). It has been observed that $2 \mathrm{D}: 4 \mathrm{D}$ ratio is related to several neuropsychiatric disorders, including; ASD (De et al., 2006), schizophrenia (Arató et al., 2004; Collinson et al., 2010), anxiety, and depressive disorders (Bailey and Hurd, 2005a), as well as different behavioral parameters (Neave et al., 2003; Bailey and Hurd, 2005b) and morphometric traits (Fink et al., 2004, 2005; Burriss et al., 2007).

\section{D:4D ratio in individuals with ASD}

Several studies have investigated 2D:4D ratios among individuals with $A S D$, and the majorities of them reported lower 2D:4D ratios in autistic probands [reviewed in Teatero and Netley (2013)]. For example, Manning et al. (2001) reported that 2D:4D ratios of autistic children, their siblings, and parents were lower than the ratio of the normal population. The results of a recent meta-analysis revealed that digit ratios of individuals with ASD are lower (0.10-0.77 standard deviations) than control subjects (Teatero and Netley, 2013).

Attention deficit hyperactivity disorder is a group of behavioral symptoms including hyperactivity, inattention, and impulsiveness. ADHD symptoms are often observed in individuals with ASD. Both disorders are more frequent in males than females (Ames and White, 2011; Davies, 2014), and it is plausible that both disorders may be related to high prenatal testosterone levels (James, 2008a). Recently, Romero-Martínez et al. (2014) investigated the relationships between ASD and ADHD symptoms through measurement of 2D:4D ratio, salivary testosterone levels, and inattention behavior of 32 parents with ASD children and their offspring. They observed that inattentive ADHD symptoms in ASD parents and their offspring were significantly associated with masculinized 2D:4D and increased salivary testosterone levels (Romero-Martínez et al., 2014).

\section{D:4D ratio in individuals with latent toxoplasmosis}

In addition to the direct effects of latent toxoplasmosis on testosterone concentration, there are also some phenotypic traits in individuals with latent toxoplasmosis that related to higher levels of prenatal testosterone (Flegr et al., 2008b; Flegr, 2010, 2013b). For example, both men and women with latent toxoplasmosis have a lower 2D:4D ratio than non-infected subjects (Flegr et al., 2005). T. gondiiinfected men are taller in stature than non-infected men (Flegr et al., 2005). The faces of infected men in photographs are more masculine and dominant than noninfected subjects when rated by women raters (Hodková et al., 2007). Unlike these findings, Manning and Fink (2011) found no significant correlations between mean national scores of $2 \mathrm{D}: 4 \mathrm{D}$ and prevalence of $T$. gondii among 23 nations (Manning and Fink, 2011). On the other hand, Lafferty (2006) found positive relationships between individual personality scores and T. gondii prevalence among different countries. These contradictory results seem to be influenced by different factors; including infection with different strains of $T$. gondii, host variations in susceptibility to infection, duration and intensity of $T$. gondii infection. Consequently, these influencing factors have diverse effects on testosterone production, behavioral alterations, and neuropsychiatric disorders (Abdoli, 2013, 2014).

\section{SEX RATIO IN INDIVIDUALS WITH ASD AND LATENT TOXOPLASMOSIS}

The ratio of boys to girls at birth is around 0.51 in most populations. Several factors, including maternal endocrine disruption, stress, and immunosuppression are believed influence this ratio (James, 2008b). According to the hormonal hypothesis (James, 2008b, 2014), high levels of testosterone in both parents and estrogen levels in mothers, around the time of conception, are associated with a higher production of sons; high levels of gonadotrophins in both parents are associated with a higher production of daughters (James, 2008b, 2014).

\section{Sex ratio in individuals with ASD}

It is very well documented that the prevalence of ASD in males are more frequent than females (Chakrabarti and Fombonne, 2001; Gillberg et al., 2006; BaronCohen et al., 2011; Werling and Geschwind, 2013; Developmental Disabilities Monitoring Network Surveillance Year 2010 Principal Investigators and Centers for Disease Control and Prevention, 2014), with ratios of 4:1 (male: female) for ASD (Chakrabarti and Fombonne, 2001) and 11:1 in AS 
(Gillberg et al., 2006). The result of recent surveillance in the United States reveals that prevalence of ASD is approximately one in 42 boys and one in 189 girls (Developmental Disabilities Monitoring Network Surveillance Year 2010 Principal Investigators and Centers for Disease Control and Prevention, 2014).

\section{Sex ratio in individuals with latent toxoplasmosis}

It has been observed that the sex ratio was significantly increased in pregnant women with high levels of anti-Toxoplasma IgG antibodies (proportion of males: 0.608 in Toxoplasma positive and 0.527 in Toxoplasma-negative mothers; $p=0.0027)$; in contrast, the sex ratio was significantly decreased in pregnant women with low levels of anti-Toxoplasma IgG antibodies (Kaňková et al., 2007a). These observations have been confirmed by the same group of researchers in a mouse model of toxoplasmosis, in which the sex ratio was increased at the early phases of infection, but then decreased in later phases (Kaňková et al., 2007b).

\section{TESTOSTERONE-RELATED MEDICAL DISORDERS IN INDIVIDUALS WITH ASD AND LATENT TOXOPLASMOSIS}

Ingudomnukul et al. (2007) reported that women suffering from ASD had significantly higher rates of testosteronerelated medical disorders (including hirsutism, bisexuality or asexuality, irregular menstrual cycle, dysmenorrhea, polycystic ovary syndrome, severe acne, epilepsy, tomboyism, and family history of ovarian and uterine cancers) compared to controls. Interestingly, mothers of children with ASD had significantly more severe acne, breast and uterine cancers, and family history of ovarian and uterine cancers, compared to controls (Ingudomnukul et al., 2007). In latent toxoplasmosis, Shirbazou et al. (2011) reported a significantly higher concentration of testosterone in women with latent toxoplasmosis than in Toxoplasma-negative women $(p=0.002)$. Moreover, infected women had significantly more facial hair $(p=0.001)$ and hair reduction $(p=0.002)$ than the control group.

Several complex neurodevelopmental disorders may be associated with higher levels of testosterone, including antisocial and aggressive behavior (Rowe et al., 2004; Ingudomnukul et al., 2007; Eisenegger et al., 2011; Romero-Martínez et al., 2014), bipolar disorder, suicidal behavior (Sher et al., 2012, 2014; Sigurdsson et al., 2014), and ADHD symptoms (Romero-Martínez et al., 2014). Interestingly, some of these disorders have been reported in individuals with latent toxoplasmosis and ASD probands. For example, ASD probands have sometime represented aggressive behaviors, self-injurious behaviors, and suicidal attempts (Lai et al., 2014). On the other hand, several testosteronerelated behavioral abnormalities (Flegr, 2007), as well as self-injurious and suicidal attempts (Arling et al., 2009; Ling et al., 2011; Pedersen et al., 2012; Zhang et al., 2012) have been reported in individuals with latent toxoplasmosis.

\section{OTHER POSSIBLE MECHANISMS OF T. GONDII THAT COULD CONTRIBUTE IN THE ETIOLOGY OF ASD}

Different mechanisms have been shown to involve in the etiology of neuropsychiatric disorders and behavioral alterations during T. gondii infection, including hormonal alterations [increased testosterone (Flegr et al., 2008a,b; Lim et al., 2013)], neurotransmitters manipulation [particularly increase dopamine and decrease serotonin (Stibbs, 1985; Skallova et al., 2006; Gaskell et al., 2009; Prandovszky et al., 2011)], decrease tryptophan and increase kynurenic acid (Schwarcz and Hunter, 2007; Notarangelo et al., 2014), and various immunological alterations (Prandota, 2010a,b, 2011). T. gondii infection also induces different abnormalities in specific regions of the brain (e.g., hippocampus and amygdala) that involved in the etiology of various neuropsychiatric disorders (Vyas et al., 2007; Hermes et al., 2008; Gatkowska et al., 2012; Mitra et al., 2013; Evans et al., 2014). Interestingly, increased dopamine levels were reported in individuals with ASD (Gillberg and Svennerholm, 1987; Previc, 2007; Nakamura et al., 2010) and AS (Nieminen-von Wendt et al., 2004). On the other hand, testosterone is also linked to dopamine (Hull et al., 1995, 2004) and both are increased during latent toxoplasmosis (Stibbs, 1985; Skallova et al., 2006; Gaskell et al., 2009; Prandovszky et al., 2011; Xiao et al., 2013). It is also observed that the connection between testosterone and dopamine is mediated by nitric oxide (NO) (Hull et al., 2004); while, increased testosterone enhances dopamine levels (Hull et al., 1995). Moreover, NO and other inflammatory cytokines such as Interleukin-2 (IL2) and IL-6 are innate defenses against T. gondii infection (Miller et al., 2009; Yarovinsky, 2014). NO, IL-2, and IL-6 also increase dopamine release (Alonso et al., 1993; Zalcman et al., 1994; Petitto et al., 1997; Prast and Philippu, 2001; West et al., 2002).

\section{CONCLUSION AND FUTURE DIRECTIONS}

Several direct and indirect evidences support the role of increased prenatal testosterone in ASD and latent toxoplasmosis. Latent toxoplasmosis may also be involved in the etiology of various testosteronerelated medical disorders and plays different roles in the etiology of neuropsychiatric disorders. Taken together with the high prevalence of latent toxoplasmosis in different nations (approximately $25-30 \%$ of the world's human population (Robert-Gangneux and Dardé, 2012); therefore, increased prevalence of ASD as well as different testosterone-related medical disorders are postulated in nations with higher prevalence of toxoplasmosis. However, more research is needed to clarify the role of latent toxoplasmosis in the etiology and epidemiology of ASD and related disorders.

\section{ACKNOWLEDGMENTS}

The authors apologize for failure to provide original citations of several worthwhile researches that were discussed in this article because of strict space limitations. The authors would like to thank the editor and reviewers for their valuable comments and suggestions, which were helpful in improving the paper.

\section{REFERENCES}

Abdoli, A. (2013). Toxoplasma gondii and neuropsychiatric diseases: strain hypothesis. Neurol. Sci. 34, 1697-1698. doi:10.1007/s10072-012-1264-x

Abdoli, A. (2014). Toxoplasma, testosterone, and behavior manipulation: the role of parasite strain, host variations, and intensity of infection. Front. Biol. 9:151-160. doi:10.1007/s11515-014-1291-5

Abdoli, A., Dalimi, A., Arbabi, M., and Ghaffarifar, F. (2014). Neuropsychiatric manifestations of latent toxoplasmosis on mothers and their offspring. J. 
Matern. Fetal Neonatal Med. 27, 1368-1374. doi: 10.3109/14767058.2013.858685

Alonso, R., Chaudieu, I., Diorio, J., Krishnamurthy, A., Quirion, R., and Boksa, P. (1993). Interleukin2 modulates evoked release of [3h] dopamine in rat cultured mesencephalic cells. J. Neurochem. 61, 1284-1290. doi:10.1111/j.1471-4159. 1993.tb13620.x

Ames, C. S., and White, S. J. (2011). Brief report: are ADHD traits dissociable from the autistic profile? Links between cognition and behaviour. J. Autism Dev. Disord. 41, 357-363. doi:10.1007/s10803-0101049-0

Arató, M., Frecska, E., Beck, C., An, M., and Kiss, H. (2004). Digit length pattern in schizophrenia suggests disturbed prenatal hemispheric lateralization. Prog. Neuropsychopharmacol. Biol. Psychiatry 28, 191-194. doi:10.1016/j.pnpbp.2003.09.020

Arling, T. A., Yolken, R. H., Lapidus, M., Langenberg, P., Dickerson, F. B., Zimmerman, S. A., et al. (2009). Toxoplasma gondii antibody titers and history of suicide attempts in patients with recurrent mood disorders. J. Nerv. Ment. Dis. 3, 905-908. doi:10.1097/NMD.0b013e3181c29a23

Auyeung, B., Ahluwalia, J., Thomson, L., Taylor, K., Hackett, G., O’Donnell, K. J., et al. (2012). Prenatal versus postnatal sex steroid hormone effects on autistic traits in children at 18 to 24 months of age. Mol. Autism 3, 17. doi:10.1186/2040-2392-3-17

Auyeung, B., Baron-Cohen, S., Ashwin, E., Knickmeyer, R., Taylor, K., and Hackett, G. (2009). Fetal testosterone and autistic traits. Br. J. Psychol. 100, 1-22. doi:10.1348/000712608X311731

Auyeung, B., Taylor, K., Hackett, G., and Baron-Cohen, S. (2010). Research Foetal testosterone and autistic traits in 18 to 24 -month-old children. Mol. Autism 1, 11. doi:10.1186/2040-2392-1-11

Bailey, A. A., and Hurd, P. L. (2005a). Depression in men is associated with more feminine finger length ratios. Pers. Individ. Differ. 39, 829-836. doi:10.1016/j.paid.2004.12.017

Bailey, A. A., and Hurd, P. L. (2005b). Finger length ratio (2D:4D) correlates with physical aggression in men but not in women. Biol. Psychol. 68, 215-222. doi:10.1016/j.biopsycho.2004.05.001

Baron-Cohen, S. (2002). The extreme male brain theory of autism. Trends Cogn. Sci. 6, 248-254. doi:10.1016/S1364-6613(02)01904-6

Baron-Cohen, S., Auyeung, B., Nørgaard-Pedersen, B., Hougaard, D., Abdallah, M., Melgaard, L., et al. (2014). Elevated fetal steroidogenic activity in autism. Mol. Psychiatry. doi:10.1038/mp.2014.48

Baron-Cohen, S., Lombardo, M. V., Auyeung, B., Ashwin, E., Chakrabarti, B., and Knickmeyer, R. (2011). Why are autism spectrum conditions more prevalent in males? PLoS Biol. 9:e1001081. doi:10.1371/ journal.pbio. 1001081

Burriss, R. P., Little, A. C., and Nelson, E. C. (2007). 2D: 4D and sexually dimorphic facial characteristics. Arch. Sex. Behav. 36, 377-384. doi:10.1007/ s10508-006-9136-1

Chakrabarti, S., and Fombonne, E. (2001). Pervasive developmental disorders in preschool children. JAMA 285, 3093-3099. doi:10.1001/jama.285.24. 3093

Collinson, S. L., Lim, M., Chaw, J. H., Verma, S., Sim, K., Rapisarda, A., et al. (2010). Increased ratio of 2nd to 4th digit (2D: 4D) in schizophrenia. Psychiatry Res. 176, 8-12. doi:10.1016/j.psychres.2009.08.023

Currenti, S. A. (2010). Understanding and determining the etiology of autism. Cell. Mol. Neurobiol. 30, 161-171. doi:10.1007/s10571-009-9453-8

Dalimi, A., and Abdoli, A. (2012). Latent toxoplasmosis and human. Iran J Parasitol 7, 1-17.

Davies, W. (2014). Sex differences in attention deficit hyperactivity disorder: candidate genetic and endocrine mechanisms. Front. Neuroendocrinol. 53:331-346. doi:10.1016/j.yfrne.2014.03.003

De, E. I., Verheij, F., Wiegman, T., and Ferdinand, R. F. (2006). Differences in finger length ratio between males with autism, pervasive developmental disorder-not otherwise specified, ADHD, and anxiety disorders. Dev. Med. Child Neurol. 48 962-965. doi:10.1017/S0012162206002118

Developmental Disabilities Monitoring Network Surveillance Year 2010 Principal Investigators, and Centers for Disease Control and Prevention (CDC). (2014). Prevalence of autism spectrum disorder among children aged 8 years - autism and developmental disabilities monitoring network, 11 sites, United States, 2010. MMWR Surveill. Summ. 63, $1-21$.

Eisenegger, C., Haushofer, J., and Fehr, E. (2011). The role of testosterone in social interaction. Trends Cogn. Sci. 15, 263-271. doi:10.1016/j.tics.2011.04. 008

Evans, A. K., Strassmann, P. S., Lee, I. P., and Sapolsky, R. M. (2014). Patterns of Toxoplasma gondii cyst distribution in the forebrain associate with individual variation in predator odor avoidance and anxiety-related behavior in male Long-Evans rats. Brain Behav. Immun. 37, 122-133. doi:10.1016/j. bbi.2013.11.012

Fink, B., Grammer, K., Mitteroecker, P., Gunz, P., Schaefer, K., Bookstein, F. L., et al. (2005). Second to fourth digit ratio and face shape. Proc. Biol. Sci. 272, 1995-2001. doi:10.1098/rspb.2005.3179

Fink, B., Manning, J. T., Neave, N., and Grammer, K. (2004). Second to fourth digit ratio and facial asymmetry. Evol. Hum. Behav. 25, 125-132. doi:10.1016/ S1090-5138(03)00084-9

Flegr, J. (2007). Effects of Toxoplasma on human behavior. Schizophr. Bull.33, 757-760. doi:10.1093/ schbul/sbl074

Flegr, J. (2010). Influence of latent toxoplasmosis on the phenotype of intermediate hosts. Folia Parasitol. (Praha) 57, 81-87. doi:10.14411/fp.2010.010

Flegr, J. (2013a). How and why Toxoplasma makes us crazy. Trends Parasitol. 29, 156-163. doi:10.1016/j. pt.2013.01.007

Flegr, J. (2013b). Influence of latent Toxoplasma infection on human personality, physiology and morphology: pros and cons of the Toxoplasma-human model in studying the manipulation hypothesis. $J$. Exp. Biol. 216, 127-133. doi:10.1242/jeb.073635

Flegr, J., Hodný, Z., Novotná, M., and Hanušová, J. (2005). Body height, body mass index, waisthip ratio, fluctuating asymmetry and second to fourth digit ratio in subjects with latent toxoplasmosis. Parasitology 130, 621-628. doi:10.1017/ S0031182005007316

Flegr, J., Lindová, J., and Kodym, P. (2008a). Sexdependent toxoplasmosis-associated differences in testosterone concentration in humans. Parasitology 135, 427-431. doi:10.1017/S0031182007004064
Flegr, J., Lindová, J., Pivoñková, V., and Havlícek, J. (2008b). Brief Communication: latent toxoplasmosis and salivary testosterone concentration -important confounding factors in second to fourth digit ratio studies. Am. J. Phys. Anthropol. 137, 479-484. doi:10.1002/ajpa.20888

Gaskell, E. A., Smith, J. E., Pinney, J. W., Westhead, D. R., and McConkey, G. A. (2009). A unique dual activity amino acid hydroxylase in Toxoplasma gondii. PLoS ONE 4:e4801. doi:10.1371/journal. pone.0004801

Gatkowska, J., Wieczorek, M., Dziadek, B., Dzitko, K., and Dlugonska, H. (2012). Behavioral changes in mice caused by Toxoplasma gondii invasion of brain. Parasitol. Res. 111, 53-58. doi:10.1007/ s00436-011-2800-y

Gesundheit, B., Rosenzweig, J. P., Naor, D., Lerer, B., Zachor, D. A., Procházka, V., et al. (2013). Immunological and autoimmune considerations of Autism spectrum disorders. J. Autoimmun. 44, 1-7. doi:10. 1016/j.jaut.2013.05.005

Gillberg, C., Cederlund, M., Lamberg, K., and Zeijlon, L. (2006). Brief report: "the autism epidemic". The registered prevalence of autism in a Swedish urban area. J. Autism Dev. Disord. 36, 429-435. doi:10.1007/s10803-006-0081-6

Gillberg, C., and Svennerholm, L. (1987). CSF monoamines in autistic syndromes and other pervasive developmental disorders of early childhood. Br. J. Psychiatry 151, 89-94. doi:10.1192/bjp.151.1. 89

Goines, P. E., and Ashwood, P. (2013). Cytokine dysregulation in autism spectrum disorders (ASD): possible role of the environment. Neurotoxicol. Teratol. 36, 67-81. doi:10.1016/j.ntt.2012.07.006

Hermes, G., Ajioka, J. W., Kelly, K. A., Mui, E., Roberts, F., Kasza, K., et al. (2008). Neurological and behavioral abnormalities, ventricular dilatation, altered cellular functions, inflammation, and neuronal injury in brains of mice due to common, persistent, parasitic infection. J. Neuroinflammation 5, 48 . doi:10.1186/1742-2094-5-48

Hodková, H., Kolbeková, P., Skallová, A., Lindová, J., and Flegr, J. (2007). Higher perceived dominance in Toxoplasma infected men - a new evidence for role of increased level of testosterone in toxoplasmosis-associated changes in human behavior. Neuro Endocrinol. Lett. 28, 110-114.

Hönekopp, J., Bartholdt, L., Beier, L., and Liebert, A. (2007). Second to fourth digit length ratio (2D: 4D) and adult sex hormone levels: new data and a meta-analytic review. Psychoneuroendocrinology 32, 313-321. doi:10.1016/j.psyneuen.2007.01.007

Hönekopp, J., and Watson, S. (2010). Meta-analysis of digit ratio 2D: $4 \mathrm{D}$ shows greater sex difference in the right hand. Am. J. Hum. Biol. 22, 619-630. doi:10.1002/ajhb.21054

Hull, E. M., Du, J., Lorrain, D. S., and Matuszewich, L. (1995). Extracellular dopamine in the medial preoptic area: implications for sexual motivation and hormonal control of copulation. J. Neurosci. 15, 7465-7471.

Hull, E. M., Muschamp, J. W., and Sato, S. (2004). Dopamine and serotonin: influences on male sexual behavior. Physiol. Behav. 83, 291-307. doi:10. 1016/S0031-9384(04)00357-9

Ingudomnukul, E., Baron-Cohen, S., Wheelwright, S., and Knickmeyer, R. (2007). Elevated rates 
of testosterone-related disorders in women with autism spectrum conditions. Horm. Behav. 51, 597-604. doi:10.1016/j.yhbeh.2007.02.001

James, W. H. (2008a). Further evidence that some male-based neurodevelopmental disorders are associated with high intrauterine testosterone concentrations. Dev. Med. Child Neurol. 50, 15-18. doi:10.1111/j.1469-8749.2007.02001.x

James, W. H. (2008b). Evidence that mammalian sex ratios at birth are partially controlled by parental hormone levels around the time of conception. $J$. Endocrinol. 198, 3-15. doi:10.1677/JOE-07-0446

James, W. H. (2014). Studies of human sex ratios at birth may lead to the understanding of several forms of pathology. Hum. Biol. 85, 769-788. doi: $10.3378 / 027.085 .0513$

Jyonouchi, H. (2013). Immunological abnormalities in autism spectrum disorders. Adv. Neuroimmune Biol. 4, 141-159.

Kaňková, Š, Šulc, J., Nouzová, K., Fajfrlík, K., Frynta, D., and Flegr, J. (2007a). Women infected with parasite Toxoplasma have more sons. Naturwissenschaften 94, 122-127. doi:10.1007/s00114006-0166-2

Kaňková, Š, Kodym, P., Frynta, D., Vavrinová, R., Kubĕna, A., and Flegr, J. (2007b). Influence of latent toxoplasmosis on the secondary sex ratio in mice. Parasitology 134, 1709-1717. doi:10.1017/ S0031182007003253

Knickmeyer, R., Baron-Cohen, S., Fane, B. A., Wheelwright, S., Mathews, G. A., Conway, G. S., et al. (2006). Androgens and autistic traits: a study of individuals with congenital adrenal hyperplasia. Horm. Behav. 50, 148-153. doi:10.1016/j.yhbeh. 2006.02 .006

Lafferty, K. D. (2006). Can the common brain parasite, Toxoplasma gondii, influence human culture? Proc. Biol. Sci. 273, 2749-2755. doi:10.1098/rspb. 2006.3641

Lai, M.-C., Lombardo, M. V., and Baron-Cohen, S. (2014). Autism. Lancet 383, 896-910. doi:10.1016/ S0140-6736(13)61539-1

Lim, A., Kumar, V., Hari Dass, S. A., and Vyas, A. (2013). Toxoplasma gondii infection enhances testicular steroidogenesis in rats. Mol. Ecol. 22, 102-110. doi: $10.1111 / \mathrm{mec} .12042$

Ling, V. J., Lester, D., Mortensen, P. B., Langenberg, P. W., and Postolache, T. T. (2011). Toxoplasma gondii seropositivity and suicide rates in women. J. Nerv. Ment. Dis. 199, 440-444. doi:10.1097/NMD. 0b013e318221416e

Lundström, S., Chang, Z., Kerekes, N., Gumpert, C., Råstam, M., Gillberg, C., et al. (2011). Autisticlike traits and their association with mental health problems in two nationwide twin cohorts of children and adults. Psychol. Med. 41, 2423-2433. doi:10.1017/S0033291711000377

Lundström, S., Chang, Z., Råstam, M., Gillberg, C., Larsson, H., Anckarsäter, H., et al. (2012). Autism spectrum disorders and autistic like traits: similar etiology in the extreme end and the normal variation. Arch. Gen. Psychiatry 69, 46-52. doi:10.1001/archgenpsychiatry.2011.144

Lutchmaya, S., Baron-Cohen, S., Raggatt, P., Knickmeyer, R., and Manning, J. (2004). 2nd to 4th digit ratios, fetal testosterone and estradiol. Early Hum. Dev. 77, 23-28. doi:10.1016/j.earlhumdev.2003.12. 002
Manning, J., and Bundred, P. (2000). The ratio of 2nd to 4th digit length: a new predictor of disease predisposition? Med. Hypotheses 54, 855-857. doi:10.1054/mehy.1999.1150

Manning, J., Kilduff, L., Cook, C., Crewther, B., and Fink, B. (2014). Digit Ratio (2D: 4D): a biomarker for prenatal sex steroids and adult sex steroids in challenge situations. Front. Endocrinol. 5:9. doi:10. 3389/fendo.2014.00009

Manning, J. T. (2011). Resolving the role of prenatal sex steroids in the development of digit ratio. Proc. Natl. Acad. Sci. U.S.A. 108, 16143-16144. doi:10.1073/pnas.1113312108

Manning, J. T., Baron-Cohen, S., Wheelwright, S., and Sanders, G. (2001). The 2 nd to 4 th digit ratio and autism. Dev. Med. Child Neurol. 43, 160-164. doi:10.1111/j.1469-8749.2001.tb00181.x

Manning, J. T., and Fink, B. (2011). Digit ratio (2D: 4D) and aggregate personality scores across nations: data from the BBC internet study. Pers. Indivd. Differ. 51, 387-391. doi:10.1016/j.paid.2010.05.040

Manning, J. T., Scutt, D., Wilson, J., and Lewis-Jones, D. I. (1998). The ratio of 2 nd to 4 th digit length: a predictor of sperm numbers and concentrations of testosterone, luteinizing hormone and oestrogen. Hum. Reprod. 13, 3000-3004. doi:10.1093/humrep/ 13.11.3000

Miller, C. M., Boulter, N. R., Ikin, R. J., and Smith, N. C. (2009). The immunobiology of the innate response to Toxoplasma gondii. Int. J. Parasitol. 39, 23-39. doi:10.1016/j.ijpara.2008.08.002

Mitra, R., Sapolsky, R. M., and Vyas, A. (2013). Toxoplasma gondii infection induces dendritic retraction in basolateral amygdala accompanied by reduced corticosterone secretion. Dis. Model Mech. 6, 516-520. doi:10.1242/dmm.009928

Montoya, J. G., and Liesenfeld, O. (2004). Toxoplasmosis. Lancet 363, 1965-1976. doi:10.1016/S01406736(04)16412-X

Nakamura, K., Sekine, Y., Ouchi, Y., Tsujii, M., Yoshikawa, E., Futatsubashi, M., et al. (2010). Brain serotonin and dopamine transporter bindings in adults with high-functioning autism. Arch. Gen. Psychiatry 67, 59-68. doi:10.1001/ archgenpsychiatry.2009.137

Neave, N., Laing, S., Fink, B., and Manning, J. T. (2003). Second to fourth digit ratio, testosterone and perceived male dominance. Proc. Biol. Sci. 270, 2167-2172. doi:10.1098/rspb.2003.2502

Nieminen-von Wendt, T. S., Metsähonkala, L., Kulomäki, T. A., Aalto, S., Autti, T. H., Vanhala, R., et al. (2004). Increased presynaptic dopamine function in Asperger syndrome. Neuroreport 15, 757-760. doi:10.1097/00001756-20040409000003

Notarangelo, F., Wilson, E., Horning, K., Thomas, M., Harris, T., Fang, Q., et al. (2014). Evaluation of kynurenine pathway metabolism in Toxoplasma gondii-infected mice: implications for schizophrenia. Schizophr. Res. 152, 261-267. doi:10.1016/j. schres.2013.11.011

Pedersen, M. G., Mortensen, P. B., Norgaard-Pedersen, B., and Postolache, T. T. (2012). Toxoplasma gondii infection and self-directed violence in mothers. Arch. Gen. Psychiatry 69, 1123-1130. doi:10.1001/ archgenpsychiatry.2012.668

Petitto, J., McCarthy, D., Rinker, C., Huang, Z., and Getty, T. (1997). Modulation of behavioral and neurochemical measures of forebrain dopamine function in mice by species-specific interleukin- 2 . J. Neuroimmunol. 73, 183-190. doi:10.1016/S01655728(96)00196-8

Prandota, J. (2010a). Neuropathological changes and clinical features of autism spectrum disorder participants are similar to that reported in congenital and chronic cerebral toxoplasmosis in humans and mice. Res. Autism Spect. Disord. 4, 103-118. doi:10.1016/j.rasd.2009.09.007

Prandota, J. (2010b). Autism spectrum disorders may be due to cerebral toxoplasmosis associated with chronic neuroinflammation causing persistent hypercytokinemia that resulted in an increased lipid peroxidation, oxidative stress, and depressed metabolism of endogenous and exogenous substances. Res. Autism Spect. Disord. 4, 119-155. doi:10.1016/j.rasd.2009.09.011

Prandota, J. (2011). Metabolic, immune, epigenetic, endocrine and phenotypic abnormalities found in individuals with autism spectrum disorders, down syndrome and Alzheimer disease may be caused by congenital and/or acquired chronic cerebral toxoplasmosis. Res. Autism Spect. Disord. 5, 14-59. doi:10.1016/j.rasd.2010.03.009

Prandovszky, E., Gaskell, E., Martin, H., Dubey, J., Webster, J. P., and McConkey, G. A. (2011). The neurotropic parasite Toxoplasma gondii increases dopamine metabolism. PLOS ONE 6:e23866. doi: 10.1371/journal.pone.0023866

Prast, H., and Philippu, A. (2001). Nitric oxide as modulator of neuronal function. Prog. Neurobiol. 64, 51-68. doi:10.1016/S0301-0082(00)00044-7

Previc, F. H. (2007). Prenatal influences on brain dopamine and their relevance to the rising incidence of autism. Med. Hypotheses 68, 46-60. doi: 10.1016/j.mehy.2006.06.041

Ratajczak, H. V. (2011). Theoretical aspects of autism: causes-a review. J. Immunotoxicol. 8, 68-79. doi:10. 3109/1547691X.2010.545086

Robert-Gangneux, F., and Dardé, M.-L. (2012). Epidemiology of and diagnostic strategies for toxoplasmosis. Clin. Microbiol. Rev. 25, 264-296. doi: 10.1128/CMR.05013-11

Romero-Martínez, Á, Polderman, T., González-Bono, E., and Moya-Albiol, L. (2014). Masculinization in parents of offspring with autism spectrum disorders could be involved in comorbid ADHD symptoms. J. Attent. Disord. doi:10.1177/ 1087054713482685

Rowe, R., Maughan, B., Worthman, C. M., Costello, E. J., and Angold, A. (2004). Testosterone, antisocial behavior, and social dominance in boys: pubertal development and biosocial interaction. Biol. Psychiatry 55, 546-552. doi:10.1016/j.biopsych.2003. 10.010

Rutter, M. (2005). Aetiology of autism: findings and questions. J. Intellect. Disabil. Res. 49, 231-238. doi:10.1111/j.1365-2788.2005.00676.x

Schwarcz, R., and Hunter, C. A. (2007). Toxoplasma gondii and schizophrenia: linkage through astrocyte-derived kynurenic acid? Schizophr. Bull. 33, 652-653. doi:10.1093/schbul/sbm030

Sher, L., Grunebaum, M. F., Sullivan, G. M., Burke, A. K., Cooper, T. B., Mann, J. J., et al. (2012). Testosterone levels in suicide attempters with bipolar disorder. J. Psychiatr. Res. 46, 1267-1271. doi:10.1016/ j.jpsychires.2012.06.016 
Sher, L., Grunebaum, M. F., Sullivan, G. M., Burke, A. K., Cooper, T. B., Mann, J. J., et al. (2014). Association of testosterone levels and future suicide attempts in females with bipolar disorder. $J$. Affect. Disord. 166, 98-102. doi:10.1016/j.jad.2014. 04.068

Shirbazou, S., Abasian, L., and Meymand, F. T. (2011). Effects of Toxoplasma gondii infection on plasma testosterone and cortisol level and stress index on patients referred to Sina hospital, Tehran. J. Microbiol. 4, 167-173.

Sigurdsson, B., Palsson, S. P., Aevarsson, O., Olafsdottir, M., and Johannsson, M. (2014). Saliva testosterone and cortisol in male depressive syndrome, a community study. The sudurnesjamenn study. Nord. J. Psychiatry 1-9. doi:10.3109/08039488. 2014.898791

Skallova, A., Kodym, P., Frynta, D., and Flegr, J. (2006). The role of dopamine in Toxoplasma-induced behavioural alterations in mice: an ethological and ethopharmacological study. Parasitology 133, 525-535. doi:10.1017/S0031182006000886

Stibbs, H. H. (1985). Changes in brain concentrations of catecholamines and indoleamines in Toxoplasma gondii infected mice. Ann. Trop. Med. Parasitol. 79, 153-157.

Teatero, M. L., and Netley, C. (2013). A critical review of the research on the extreme male brain theory and digit ratio (2D: 4D). J. Autism Dev. Disord. 43, 2664-2676. doi:10.1007/s10803-0131819-6

Vyas, A., Kim, S.-K., Giacomini, N., Boothroyd, J. C., and Sapolsky, R. M. (2007). Behavioral changes induced by Toxoplasma infection of rodents are highly specific to aversion of cat odors. Proc. Natl.
Acad. Sci. U.S.A. 104, 6442-6447. doi:10.1073/pnas. 0608310104

Werling, D. M., and Geschwind, D. H. (2013). Sex differences in autism spectrum disorders. Curr. Opin. Neurol. 26, 146-153. doi:10.1097/WCO. 0b013e32835ee548

West, A. R., Galloway, M. P., and Grace, A. A. (2002). Regulation of striatal dopamine neurotransmission by nitric oxide: effector pathways and signaling mechanisms. Synapse 44, 227-245. doi:10.1002/ syn. 10076

Xiao, J., Li, Y., Jones-Brando, L., and Yolken, R. H. (2013). Abnormalities of neurotransmitter and neuropeptide systems in human neuroepithelioma cells infected by three Toxoplasma strains. J. Neural Transm. 120, 1631-1639. doi:10.1007/s00702-0131064-3

Xu, X.-J., Shou, X.-J., Li, J., Jia, M.-X., Zhang, J.-S., Guo, Y., et al. (2013). Mothers of autistic children: lower plasma levels of oxytocin and arg-vasopressin and a higher level of testosterone. PLoS ONE 8:e74849. doi:10.1371/journal.pone.0074849

Yarovinsky, F. (2014). Innate immunity to Toxoplasma gondii infection. Nat. Rev. Immunol. 14, 109-121. doi:10.1038/nri3598

Zalcman, S., Green-Johnson, J. M., Murray, L., Nance, D. M., Dyck, D., Anisman, H., et al. (1994). Cytokine-specific central monoamine alterations induced by interleukin-1,-2 and-6. Brain Res. 643 , 40-49. doi:10.1016/0006-8993(94)90006-X

Zghair, K. H., AL-Qadhi, B. N., and Mahmood, S. H. (2014). The effect of toxoplasmosis on the level of some sex hormones in males blood donors in Baghdad. J. Parasit. Dis. 1-8. doi:10.1007/s12639-0130382-6
Zhang, Y., Traskman-Bendz, L., Janelidze, S., Langenberg, P., Saleh, A., Constantine, N., et al. (2012). Toxoplasma gondii immunoglobulin $\mathrm{G}$ antibodies and nonfatal suicidal self-directed violence. $J$. Clin. Psychiatry 73, 1069-1076. doi:10.4088/JCP. $11 \mathrm{~m} 07532$

Zheng, Z., and Cohn, M. J. (2011). Developmental basis of sexually dimorphic digit ratios. Proc. Natl. Acad. Sci. U.S.A. 108, 16289-16294. doi:10.1073/ pnas. 1108312108

Conflict of Interest Statement: The authors declare that the research was conducted in the absence of any commercial or financial relationships that could be construed as a potential conflict of interest.

Received: 14 June 2014; accepted: 09 September 2014; published online: 24 September 2014.

Citation: Abdoli A and Dalimi A (2014) Are there any relationships between latent Toxoplasma gondii infection, testosterone elevation, and risk of autism spectrum disorder? Front. Behav. Neurosci. 8:339. doi: 10.3389/fnbeh.2014.00339

This article was submitted to the journal Frontiers in Behavioral Neuroscience.

Copyright (c) 2014 Abdoli and Dalimi. This is an openaccess article distributed under the terms of the Creative Commons Attribution License (CC BY). The use, distribution or reproduction in other forums is permitted, provided the original author(s) or licensor are credited and that the original publication in this journal is cited, in accordance with accepted academic practice. No use, distribution or reproduction is permitted which does not comply with these terms. 